\title{
Effects of Flubendiamide and A Lactic Acid Bacterial Formulation on Stem Borer Scirpophaga incertulas Walker and its Parasitoids in Rice
}

\section{G. Arulkumar ${ }^{1}$, Y.S. Johnson Thangaraj Edward ${ }^{2 *}$, K. Bhuvaneswari ${ }^{3}$, P. Jeyaprakash ${ }^{4}$, N. Chandra Sekaran ${ }^{5}$ and M. Senthilkumar ${ }^{6}$}

${ }^{I}$ Department of Agricultural Entomology, Tamil Nadu Agricultural University, Coimbatore -641 003, Tamil Nadu, India

${ }^{2}$ Department of Agricultural Entomology, AC \& RI, Vazhavachanur - 606 753,

Tamil Nadu, India

${ }^{3}$ Department of Agricultural Entomology, CPPS, TNAU, Coimbatore -641 003,

Tamil Nadu, India

${ }^{4}$ Department of Plant Breeding and Genetics, ADAC \& RI, Navalur,

Kuttapattu- 620 009, Tamil Nadu, India

${ }^{5}$ Department of Soil Science and Agriculture Chemistry, TNAU, Coimbatore-641 003,

Tamil Nadu, India

${ }^{6}$ Department of Agriculture Microbiology, AC \& RI, Eachangkottai- 614 902,

Tamil Nadu, India

*Corresponding author

\section{Keywords}

Flubendiamide, Lactic acid bacteria, Yellow stem borer, Egg parasitoids

\section{Article Info}

Accepted: 07 October 2019 Available Online: 10 November 2019

\section{A B S T R A C T}

Pesticides are predominantly used to manage rice yellow stem borer (YSB), Scirpophaga incertulas Walker, killing both pests and natural enemies. Used as biofertilizers, phytostimulators, rhizoremediators and biopesticides in crop production, lactic acid bacteria (LAB) are likely to reduce the impact of pesticides on natural enemies, if compatible. In this study, an $\mathrm{LAB}$ formulation made from milk-powder, cane jaggery and egg was evaluated in combination with flubendiamide against $S$. incertulas and its egg parasitoids (Tetrastichus schoenobii Ferriere and Telenomus sp.) in replicated field trials and in laboratory. The results indicated that the LAB formulation significantly enhanced not only the efficacy of flubendiamide 20 WG@ 25 or $50 \mathrm{~g}$ a.i. $\mathrm{ha}^{-1}$, probably from its adjuvant action, but also the extent of parasitization by the parasitoids, which is discussed. 


\section{Introduction}

Primary source of income and employment for more than 200 million households across countries in the developing world (FAO, 2004), rice (Oryza sativa L.) is the staple food for nearly half of the world's population, closely associated with food security (FAO, WFP and IFAD, 2012). Limiting its production among insect pests are stem borers and leaf folders (Asghar et al., 2009). Though five species of stem borers occur in India, the yellow stem borer (YSB), Scirpophaga incertulas Walker is the most widespread and destructive. The larvae of this monophagous pest bore into the stem and destroy the growing tips by feeding on the internal contents. This in turn disrupts the flow of water and nourishment to the plant, thereby causing 'dead hearts' at the vegetative stage (Jadhao and Khurad, 2012) and 'white ears' at the reproductive stage (Chatterjee and Mondal, 2014), accounting for 50 per cent of all insecticides used in rice targeting them (Huesing and English, 2004). Often farmers apply pesticides just before harvest to avoid injury to crops even as the use of insecticides is considered an essential management practice in rice to ensure the yield potential and grain quality (Silva et al., 2002; Tindall et al., 2005). However, improper and extensive use of pesticides destroys natural enemies, causes resurgence, and results in pesticide residues in food (Jiries et al., 2002; Yu and Zhou, 2005). For instance, the Hymenopteran parasitoids, Telenomus dignus (Gahan) (Scelionidae), Tetrastichus schoenobii Ferriere (Eulophidae) and Trichogramma japonicum Ashmead (Trichogrammatidae) are three important YSB egg parasitoids, which play a pivotal role in YSB population regulation (Rama Gopala Varma et al., 2013). They need to be conserved as well. Generally regarded as safe (GRAS) food-grade microorganisms, the probiotic lactic acid bacteria (LAB) are used to improve human and animal health
(FAO/WHO, 2001). It has been estimated that $25 \%$ of the European diet and $60 \%$ of the diet in many developing countries consist of fermented foods (Stiles, 1996). LAB associated with fermented foods include species of the genera Carnobacterium, Enterococcus, Lactobacillus, Lactococcus, Leuconostoc, Oenococcus, Pediococcus, Streptococcus, Tetragenococcus, Vagococcus and Weissella (Stiles and Holzapfel, 1997; Beasley, 2004), especially Lactobacillus, Leuconostoc, Pediococcus, Lactococcus and Streptococcus (Ouwehand et al., 2002). Their inoculants are safe, easy to apply, and noncorrosive to machine (Filya et al., 2000). They have also been exploited in crop production as biofertilizers, phytostimulators, rhizoremediators and biopesticides (Noumavo et al., 2014; Munees and Kibret, 2014). Some LAB species act as silage additives, improving the silage fermentation process (Yunus et al., 2000; Kuikui et al., 2015). They even are capable of degrading pesticides (Zhang et al., 2014). Flubendiamide is one of the recommended insecticides against $S$. incertulas. This study was undertaken to lessen the impact of a commercially available formulation of flubendiamide on egg parasitoids of $S$. incertulas by using a homemade preparation of LAB formulation without affecting the efficacy of flubendiamide.

\section{Materials and Methods}

Field experiments were conducted at the Paddy Breeding Station of Tamil Nadu Agricultural University (TNAU), Coimbatore, one each during Kharif (May, 2018 - August, 2018) and Rabi seasons (December, 2018 April, 2019). There were six treatments replicated four times in a randomized blocks design (RBD) wherein 21-day old rice seedlings (var. Co 51) were transplanted at a spacing of $20 \times 20 \mathrm{~cm}$ in $6 \times 5 \mathrm{~m}^{2}$ size plots with $1 \mathrm{~m}$ replication border and $0.5 \mathrm{~m}$ treatment border between the plots, receiving 
regular agronomic practices. In a discriminate fermentation process (David et al., 2018), the lactic acid bacterial formulation was prepared by mixing $100 \mathrm{~g}$ milk powder and $1.0 \mathrm{~kg}$ cane jaggery, $100 \mathrm{ml}$ one-day fermented grape juice and a beaten egg. This semisolid product containing LAB ferments was first diluted in 4 parts of water, left overnight for rapid LAB multiplication, and sprayed at $2.5 \%(25 \mathrm{ml}$ per litre of water) the next day. Two rounds of foliar spray were made at 2-week interval, starting at 35 days after transplanting, using a knapsack battery-operated sprayer with 500 litre spray fluid per hectare. The control plots received no spray. The injury caused by $S$. incertulas (dead hearts / white ears) in percentage was recorded from 10 randomly selected hills per plot at 7-day interval post treatment (Heinrichs et al., 1985).

Stem borer egg masses along with leaf bits (5$7 \mathrm{~cm}$ ) were collected from each plot at weekly interval to record the extent of parasitization in the laboratory. The collected egg masses on leaves were maintained individually in clothcovered test tubes secured with rubber band (12 mm dia., $5 \mathrm{~cm}$ length) under laboratory conditions $\left(34{ }^{0} \mathrm{C}, 80 \% \mathrm{RH}\right)$ until the parasitoids and/or the host larvae emerged out from the egg masses (Manju et al., 2002).

The test tubes were kept in trays with $2.5 \mathrm{~cm}$ water to maintain the moisture content and they were regularly monitored for the emergence of egg parasitoids and the species. The emerged parasitoids and the stem borer larvae were counted under a low power stereo zoom microscope.

Ten days later, the egg masses were dissected to count the unemerged parasitoid adults, pupae and unhatched yellow stem borer larvae (YSB larva) and included in the totals while analyzing the data. The percent parasitization was calculated using the formula of Reuolin and Soundararajan (2017).
Parasitization \%

Number of parasitoids emerged

= ----------------------------------------------X 100

Number of parasitoids emerged

+ SB larvae hatched + unhatched eggs

The data thus obtained from all the observations were subjected to appropriate statistical analysis after suitable transformations.

\section{Results and Discussion}

\section{S. incertulas caused dead heart}

In both seasons, the extent of dead hearts caused by $S$. incertulas differed significantly among the treatments (Table 1 - 3). Pooled analysis of the two-season data indicated that the dead heart damage was significantly lower in all sprayed plots than in untreated control plots (Table 3). Among the treatments, the injury was significantly lowest in plots where flubendiamide $20 \mathrm{WG} @ 50 \mathrm{~g}$ a.i. ha ${ }^{-1}+\mathrm{LAB}$ was sprayed (2.44\%), followed by flubendiamide $20 \mathrm{WG} @ 50 \mathrm{~g}$ a.i. ha ${ }^{-1}$ (3.74\%), flubendiamide 20 WG @ 25 g a.i. $\mathrm{ha}^{-1}+$ LAB (4.1\%), and flubendiamide $20 \mathrm{WG}$ @ $25 \mathrm{~g}$ a.i. $\mathrm{ha}^{-1}(5.63 \%)$ The damage was also significantly lower in LAB-sprayed plots $(14.22 \%)$ than in control plots $(18.61 \%)$ but higher than that in other plots. Season wise too, flubendiamide $20 \mathrm{WG}$ @ $50 \mathrm{~g}$ a.i. ha ${ }^{-1}+$ LAB was the most effective treatment (1.95 $2.93 \%$ ), followed by flubendiamide $20 \mathrm{WG}$ @ $50 \mathrm{~g}$ a.i. $\mathrm{ha}^{-1}(3.19$ - $4.29 \%)$, flubendiamide $20 \mathrm{WG} @ 25 \mathrm{~g}$ a.i. ha ${ }^{-1}+\mathrm{LAB}$ (3.59 - 4.6\%), and flubendiamide 20 WG @ $25 \mathrm{~g}$ a.i. $\mathrm{ha}^{-1}(4.78-6.48 \%)$ (Table 1 and 2). Though effective, LAB, when sprayed alone, was inferior to flubendiamide in combination with or without LAB (13.32 - $15.11 \%)$. Compared to the level of dead heart in control plots, flubendiamide $20 \mathrm{WG} @ 50 \mathrm{~g}$ a.i. ha ${ }^{-1}+$ LAB reduced the dead heart damage by 85.19 - 88.77 per cent, flubendiamide 20 WG @ 50 
g a.i. $\mathrm{ha}^{-1}$ by 78.34 - 81.66 per cent, flubendiamide 20 WG @ $25 \mathrm{~g}$ a.i. ha ${ }^{-1}+$ LAB by $76.78-79.38$ per cent, flubendiamide 20 WG @ 25 g a.i. ha ${ }^{-1} 67.31$ - 72.52 per cent, and LAB by 23.47 - 23.74 per cent (Fig. 1). Pooled analysis of the data from the two seasons also indicated that flubendiamide 20 WG @ 50 g a.i. ha ${ }^{-1}+$ LAB reduced the injury by 86.87 per cent, followed by flubendiamide 20 WG @ $50 \mathrm{~g}$ a.i. ha ${ }^{-1}$ by $79.9 \%$, flubendiamide 20 WG @ $25 \mathrm{~g}$ a.i. ha ${ }^{-1}+$ LAB by 78 per cent, flubendiamide 20 WG @ $25 \mathrm{~g}$ a.i. ha ${ }^{-1}$ by 69.75 per cent, and LAB by 23.61 per cent than in control plots.

\section{S. incertulas caused white ears}

Similarly, when compared to the control, white ears due to $S$. incertulas were significantly lower in all plots in both seasons (Table 4) and pooled analysis of the data from the two seasons also indicated that white ear injury was significantly lower in all plots than in control plots (Table 4). Among the treatments, white ears were fewer in plots where flubendiamide $20 \mathrm{WG} @ 50 \mathrm{~g}$ a.i. ha ${ }^{-1}$ + LAB was sprayed (2.06\%), followed by flubendiamide $20 \mathrm{WG} @ 25 \mathrm{~g}$ a.i. ha ${ }^{-1}+\mathrm{LAB}$ (2.90\%), on par with flubendiamide 20 WG @ $50 \mathrm{~g}$ a.i. $\mathrm{ha}^{-1}(3.12 \%)$, and flubendiamide 20 WG @ $25 \mathrm{~g}$ a.i. ha ${ }^{-1}(4.95 \%)$ The damage was significantly lower in LAB-sprayed plots $(12.71 \%)$ than in control plots $(16.26 \%)$ but higher than that in other plots.

\section{Egg parasitoids}

Parasitization by the YSB eggs by the parasitoids, especially Tetrastichus schoenobii and Telenomus sp., (Plate 1) was significantly less on plants in plots sprayed with fluebendiamide with or without LAB than on plants in plots sprayed with LAB alone or nospray control. In both seasons (Table 5 and 6), parasitization by $T$. schoenobii was significantly minimum in plots treated with flubendiamide $20 \mathrm{WG} @ 50 \mathrm{~g}$ a.i. ha ${ }^{-1}$ with or without LAB (15.5 - $17.54 \%$ in Season -1 to $19.0-21.63 \%$ in Season - 2), followed by flubendiamide $20 \mathrm{WG} @ 25 \mathrm{~g}$ a.i. ha ${ }^{-1}$ in mixture with or without LAB (20.67 - 29.76 in Season - 1 to 26.74 - $35.95 \%$ in Season 2). Parasitization by T. schoenobii was significantly highest in plots where LAB was sprayed alone (48.34\% in Season - 1 to 55.82 $\%$ in Season - 2), followed by control (37.0 \% in Season -1 to $55.82 \%$ in Season - 2). The pooled analysis of the data from the two seasons also indicated the same results with $T$. schoenobii parasitizing most egg masses when LAB or none is sprayed $(39.05-52.08 \%)$ than when flubendiamide was sprayed at low or high concentration with or without LAB $(17.25-32.82 \%)$ (Table 7).

Parasitization by the egg parasitoid, Telenomus sp. was also significantly highest on egg masses in LAB-sprayed plots $(23.82 \%$ in Season $-1,25.89 \%$ in Season -2 ), followed by on egg masses in control plots $(16.90 \%$ in Season $-1,20.51 \%$ in Season 2 ), than in other plots where flubendiamide was sprayed with or without LAB (8.42 $15.28 \%$ in Season -1 to $6.70-19.15 \%$ in Season - 2) (Table 8 and 9). The pooled twoseason data also indicated the same trend in parasitization by Telenomous sp., significantly higher after LAB spray (24.85\%) and nospray control (18.71\%), and significantly lower after flubendiamide sprays with or without LAB (6.93 - 17.21\%) (Table 10 and Fig. 2).

Insecticides are indispensable to manage pests like rice stem borers. However, they need to be safer to the natural enemies. Moreover, they can also be made safer. For instance, flubendiamide $20 \mathrm{WG}$ has been reportedly safe to several natural enemies, including spiders and coccinellids in sugarcane field (Madhu Sudhanan et al., 2017), to mirid predators of tomato pests (Wanumen et al., 
2016) and rice pests (Lakshmi et al., 2010), and to the predatory mites under laboratory conditions (Maxime et al., 2011). The results of this investigation highlight that the LAB can make it even safer without decreasing its efficacy. It is well known that flubendiamide $20 \mathrm{WG}$, one of the new generation diamide group of pesticides, is significantly effective against Lepidopteran pests, especially leaf folder and stem borer in rice. Evaluation of this formulation in this study also revealed that it was significantly more effective at the higher dose $50 \mathrm{~g}$ a.i. ha $^{-1}$ dose in reducing the dead hearts caused by $S$. incertulas as high as 78.34 - 81.66 per cent.

A different formulation, flubendiamide 480 SC @ 24 and $30 \mathrm{~g}$ a.i./ha has earlier been reported as highly effective against rice leaffolder at various places (Sekh et al., 2007; Prasad et al., 2014; Devi and Singh, 2016; Sandhu and Dhaliwal, 2016; Shyamrao and Raghuraman, 2019). However, flubendiamide 20 WG@50 g a.i. ha ${ }^{-1}$ was found even more effective when LAB was mixed with this formulation $(85.15-88.77 \%)$, indicative of its additive effect. Similarly, at the lower dose of $25 \mathrm{~g}$ a.i. ha ${ }^{-1}$, it reduced the dead hearts by 67.31- 72.55 per cent, while, with LAB, it lowered the damage even higher by $76.78-$ 79.38 per cent. The lower dose of flubendiamide $25 \mathrm{WG} \mathrm{g}$ a.i. $\mathrm{ha}^{-1}$ too, with or without LAB, reduced the dead heart by 69.75- 78 per cent as high as the higer dose 50 g a.i. $\mathrm{ha}^{-1}$, reducing the damage by $79.9-$ 86.87 per cent (Fig. 1).

This shows the potential of LAB in increasing the efficacy of flubendiamide by $5.0-15.0$ per cent, probably because of the adjuvant qualities of the formulation resulting in better wetting, sticking and spreading. LAB is ubiquitous members of many plant microbiomes. One of the LAB, Lactobacilli are found in phyllosphere, endosphere and rhizosphere of many plants and ferments containing $\mathrm{LAB}$ are exploited in agriculture as biocontrol agents, biofertilizers and biostimulants (Lamont et al., 2017). They are gram positive, facultative anaerobic bacteria often found in substrates rich in carbohydrates which they convert into organic acids. Many species of LAB occur as epiphytics (Harshini Priya, 2016).

Probably, their volatiles are likely to modulate the abundance on plants of insects, pests or natural enemies as microbial volatiles attract or repel insects by eliciting behavioural changes (Davis et al., 2013) and Venu et al., (2014) have demonstrated that volatiles derived from microbes are responsible for long distance attraction of fruit flies to their food sources.

In this investigation, LAB itself has helped reduce the stem borer caused damage by 23.47 $-23.74 \%$, probably it may cause the plants less attractive to stem borer moths, which needs to be studied in future. On the other hand, parasitism by the egg parasitoids was significantly more in LAB-sprayed plots than in all other plots, including unsprayed control.

For instance, T. schoenobii and Telenomus sp. had been significantly more active after LAB sprays (17.21 - $32.82 \%)$ than after flubeniamide sprays, alone at both concentrations (11.24 - $23.70 \%)$. Generally, YSB egg masses are parasitized by more than one species of parasitiods, viz., Trichogramma spp. + Telenomus spp (3.46\%), Telenomus + Tetrastichus $(21.06 \%)$ and Trichogramma + Tetrastichus $(2.35 \%)$, the extent of parasitism ranging from $4.0 \%$ to $97.2 \%$ in different parts of India (Senapati et al., 1999; Chakraborty, 2012). When mixed to flubendiamide, LAB appeared to have reduced flubendiamide toxicity only to these beneficial insects but not to $S$. incertulas, i.e. LAB is safer to natural enemies even when mixed with pesticides like flubendiamide. 
Table.1 Effect of flubendiamide $20 \mathrm{WG}$ and LAB on dead hearts due to $S$. incertulas in rice in season - 1

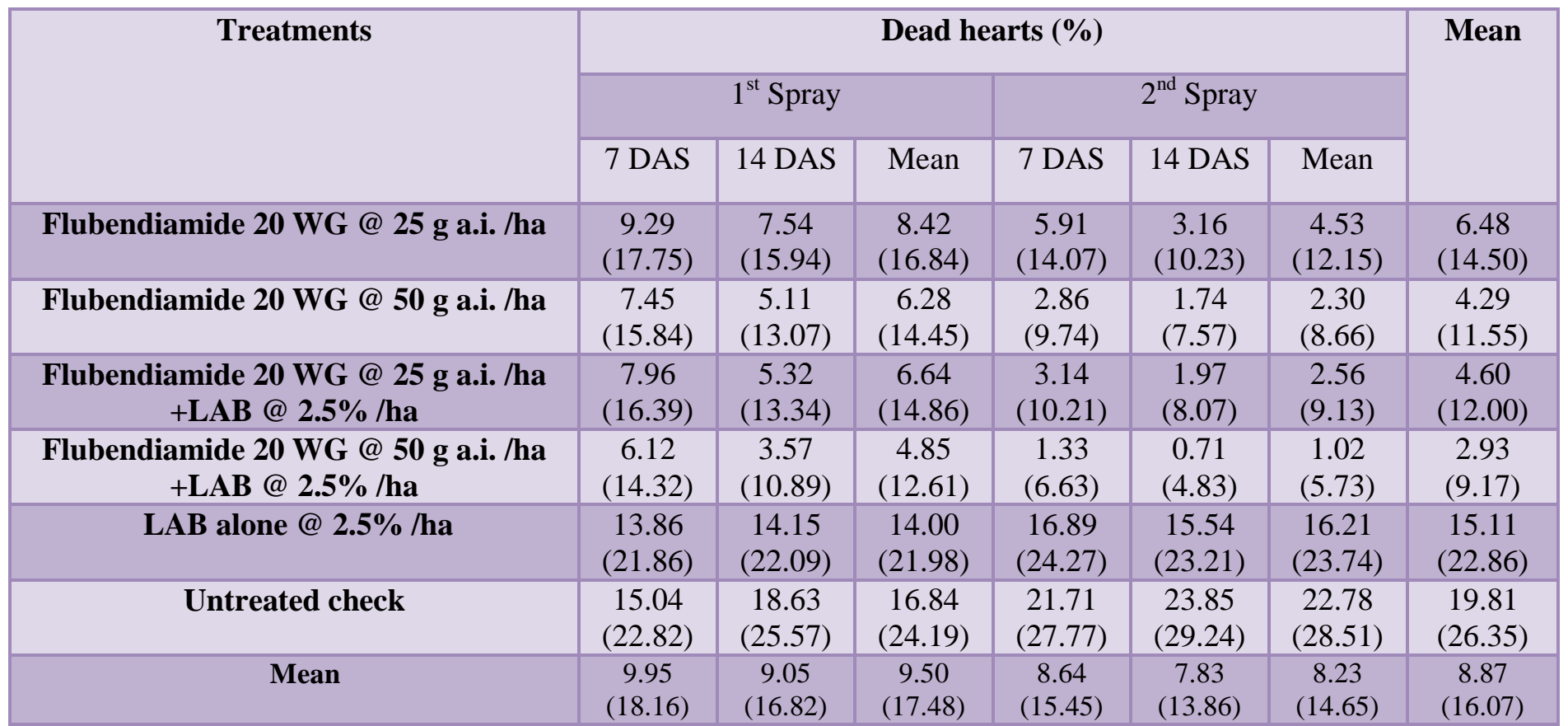

(LAB, lactic acid bacteria; DAS, days after spray; values in parentheses are arc sine transformed values; mean of four replications)

\begin{tabular}{|c|c|c|c|c|c|c|c|}
\hline & & SE.d & $\begin{array}{c}\text { CD } \\
(P=0.05)\end{array}$ & & & SE.d & $\begin{array}{c}\text { CD } \\
(\mathbf{P}=\mathbf{0 . 0 5})\end{array}$ \\
\hline Between Treatments & : & 0.09 & 0.19 & Treatments x DAS & : & 0.13 & 0.26 \\
\hline Between DAS & : & 0.05 & 0.11 & Treatments x Spray & : & 0.13 & 0.26 \\
\hline Between Spray & : & 0.05 & 0.11 & Treatments x DAS x Spray & : & 0.19 & 0.37 \\
\hline DAS x Spray & : & 0.08 & 0.15 & & & & \\
\hline
\end{tabular}


Table.2 Effect of flubendiamide $20 \mathrm{WG}$ and LAB on dead hearts due to $S$. incertulas in rice in season -2

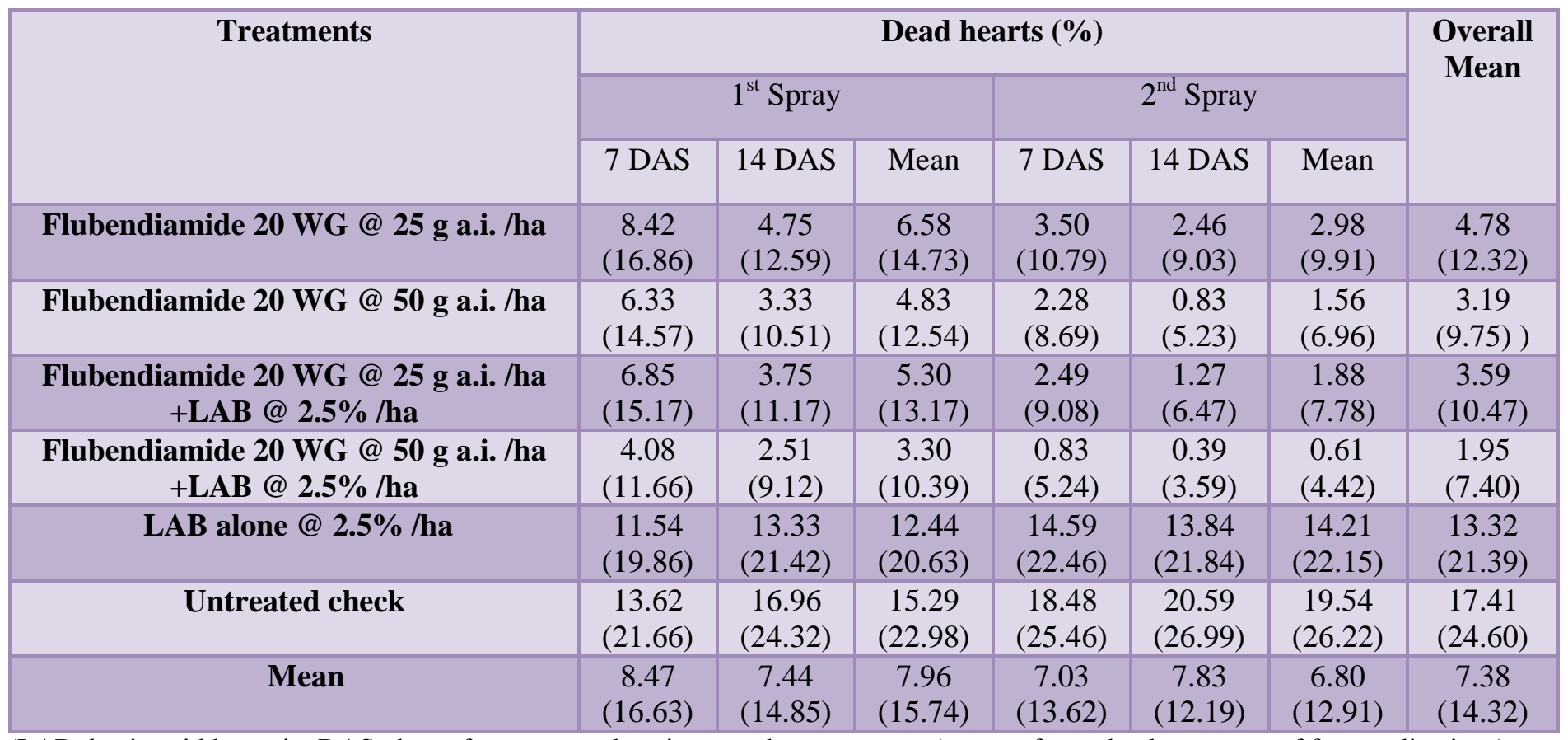

(LAB, lactic acid bacteria; DAS, days after spray; values in parentheses are arc sine transformed values; mean of four replications)

\begin{tabular}{|c|c|c|c|c|c|c|c|}
\hline & & SE.d & $\begin{array}{c}\text { CD } \\
(P=0.05)\end{array}$ & & & SE.d & $\begin{array}{c}\text { CD } \\
(\mathbf{P}=\mathbf{0 . 0 5})\end{array}$ \\
\hline Between Treatments & : & 0.12 & 0.25 & Treatments x DAS & : & 0.17 & 0.35 \\
\hline Between DAS & : & 0.07 & 0.14 & Treatments x Spray & : & 0.17 & 0.35 \\
\hline Between Spray & : & 0.07 & 0.14 & Treatments x DAS x Spray & : & 0.25 & 0.49 \\
\hline DAS x Spray & : & 0.10 & 0.20 & & & & \\
\hline
\end{tabular}


Table.3 Effect of flubendiamide $20 \mathrm{WG}$ and LAB on dead hearts due to $S$. incertulas in rice in pooled season $1 \& 2$ (pooled)

\begin{tabular}{|c|c|c|c|c|c|c|c|}
\hline \multirow[t]{3}{*}{ Treatments } & \multicolumn{6}{|c|}{ Mean dead hearts } & \multirow{3}{*}{$\begin{array}{c}\text { Pooled } \\
\text { Mean }\end{array}$} \\
\hline & \multicolumn{3}{|c|}{$1^{\text {st }}$ Spray } & \multicolumn{3}{|c|}{$2^{\text {nd }}$ Spray } & \\
\hline & 7 DAS & 14 DAS & Mean & $7 \mathrm{DAS}$ & $14 \mathrm{DAS}$ & Mean & \\
\hline Flubendiamide 20 WG @ 25 g a.i. /ha & $\begin{array}{c}8.85 \\
(17.30)\end{array}$ & $\begin{array}{c}6.15 \\
(14.27)\end{array}$ & $\begin{array}{c}7.50 \\
(15.79)\end{array}$ & $\begin{array}{c}4.71 \\
(14.43)\end{array}$ & $\begin{array}{c}2.81 \\
(9.63)\end{array}$ & $\begin{array}{c}3.76 \\
(11.03)\end{array}$ & $\begin{array}{c}5.63 \\
(13.41)\end{array}$ \\
\hline Flubendiamide 20 WG @ 50 g a.i. /ha & $\begin{array}{c}6.89 \\
(15.20)\end{array}$ & $\begin{array}{c}4.22 \\
(11.79)\end{array}$ & $\begin{array}{c}5.55 \\
(13.49)\end{array}$ & $\begin{array}{l}2.57 \\
(9.21)\end{array}$ & $\begin{array}{l}1.28 \\
(6.40)\end{array}$ & $\begin{array}{l}1.93 \\
(7.80)\end{array}$ & $\begin{array}{c}3.74 \\
(10.65)\end{array}$ \\
\hline $\begin{array}{c}\text { Flubendiamide } 20 \text { WG @ } 25 \text { g a.i. /ha } \\
\text { +LAB @ 2.5\% /ha }\end{array}$ & $\begin{array}{c}7.41 \\
(15.78)\end{array}$ & $\begin{array}{c}4.54 \\
(12.25)\end{array}$ & $\begin{array}{c}5.97 \\
(14.02)\end{array}$ & $\begin{array}{c}2.82 \\
(9.64)\end{array}$ & $\begin{array}{c}1.62 \\
(7.27)\end{array}$ & $\begin{array}{c}2.22 \\
(8.46)\end{array}$ & $\begin{array}{c}4.10 \\
(11.24)\end{array}$ \\
\hline $\begin{array}{c}\text { Flubendiamide } 20 \text { WG @ } 50 \text { g a.i. /ha } \\
\text { +LAB @ 2.5\% /ha }\end{array}$ & $\begin{array}{c}5.10 \\
(12.99)\end{array}$ & $\begin{array}{c}3.04 \\
(10.00)\end{array}$ & $\begin{array}{c}4.07 \\
(11.50)\end{array}$ & $\begin{array}{c}1.08 \\
(5.93)\end{array}$ & $\begin{array}{c}0.55 \\
(4.21)\end{array}$ & $\begin{array}{c}0.82 \\
(5.07)\end{array}$ & $\begin{array}{c}2.44 \\
(8.28)\end{array}$ \\
\hline LAB alone @ 2.5\% /ha & $\begin{array}{l}12.70 \\
(20.86)\end{array}$ & $\begin{array}{l}13.74 \\
(21.75)\end{array}$ & $\begin{array}{c}13.22 \\
(21.30)\end{array}$ & $\begin{array}{c}15.74 \\
(23.36)\end{array}$ & $\begin{array}{c}14.69 \\
(22.53) \\
\end{array}$ & $\begin{array}{l}15.21 \\
(22.94)\end{array}$ & $\begin{array}{c}14.22 \\
(22.12)\end{array}$ \\
\hline Untreated check & $\begin{array}{c}14.33 \\
(22.24)\end{array}$ & $\begin{array}{c}17.80 \\
(24.94)\end{array}$ & $\begin{array}{c}16.06 \\
(23.59)\end{array}$ & $\begin{array}{c}20.10 \\
(26.61)\end{array}$ & $\begin{array}{c}22.22 \\
(28.11)\end{array}$ & $\begin{array}{c}21.16 \\
(27.36)\end{array}$ & $\begin{array}{c}18.61 \\
(25.48)\end{array}$ \\
\hline Mean & $\begin{array}{c}9.21 \\
(17.39)\end{array}$ & $\begin{array}{c}8.25 \\
(15.83)\end{array}$ & $\begin{array}{c}8.73 \\
(16.61)\end{array}$ & $\begin{array}{c}7.84 \\
(14.53)\end{array}$ & $\begin{array}{c}7.20 \\
(13.02)\end{array}$ & $\begin{array}{c}7.52 \\
(13.78)\end{array}$ & $\begin{array}{c}8.12 \\
(15.20)\end{array}$ \\
\hline
\end{tabular}

(LAB, lactic acid bacteria; DAS, days after spray; values in parentheses are arc sine transformed values; mean of four replications)

\begin{tabular}{|c|c|c|c|c|c|c|c|}
\hline & & SE.d & $\begin{array}{c}\text { CD } \\
(P=0.05)\end{array}$ & & & SE.d & $\begin{array}{c}\text { CD } \\
(P=0.05)\end{array}$ \\
\hline Between Treatments & : & 0.08 & 0.15 & Treatments x DAS & : & 0.11 & 0.21 \\
\hline Between DAS & : & 0.04 & 0.09 & Treatments x Spray & : & 0.11 & 0.22 \\
\hline Between Spray & $:$ & 0.04 & 0.09 & Treatments x DAS x Spray & : & 0.15 & 0.30 \\
\hline DAS x Spray & : & 0.06 & 0.12 & & & & \\
\hline
\end{tabular}


Table.4 Effect of flubendiamide $20 \mathrm{WG}$ and LAB on white ears due to $S$. incertulas in rice in season - $1 \& 2$ (pooled)

\begin{tabular}{|c|c|c|c|}
\hline \multirow{2}{*}{ Treatments } & \multicolumn{2}{|c|}{ White ears (\%) } & Pooled mean \\
& $1^{\text {st }}$ Spray & $2^{\text {nd }}$ Spray & $\begin{array}{c}\text { (\%) } \\
\text { (\%) }\end{array}$ \\
& & & 4.95 \\
\hline Flubendiamide 20 WG @ 25 g a.i. /ha & 5.02 & 4.87 & $(12.81)$ \\
\hline Flubendiamide 20 WG @ 50 g a.i. /ha & $(12.91)$ & $(12.72)$ & 3.12 \\
& 3.75 & 2.49 & $(10.05)$ \\
\hline Flubendiamide 20 WG @ 25 g a.i. /ha +LAB & $(11.13)$ & $(8.98)$ & 2.90 \\
@ 2.5\% /ha & $(10.40)$ & $(9.05)$ & $(9.72)$ \\
\hline Flubendiamide 20 WG @ 50 g a.i. /ha +LAB & 2.89 & 1.22 & 2.06 \\
@ 2.5\% /ha & $(9.71)$ & $(6.35)$ & $(8.02$ \\
\hline LAB alone @ 2.5\% /ha & 13.71 & 11.71 & 12.71 \\
& $(21.73)$ & $(20.01)$ & $(20.87)$ \\
\hline Untreated check & 17.28 & 15.24 & 16.26 \\
& $(24.56)$ & $(22.98)$ & $(23.77)$ \\
\hline Mean & 7.65 & 6.35 & 7.00 \\
& $(15.07)$ & $(13.35)$ & $(14.21)$ \\
\hline
\end{tabular}

(LAB, lactic acid bacteria; DAS, days after spray; values in parentheses are arc sine transformed values; mean of four replications)

\begin{tabular}{|c|c|c|c|}
\hline & & SE.d & $\begin{array}{c}\text { CD } \\
(\mathbf{P = 0 . 0 5})\end{array}$ \\
\hline Between Treatments & $:$ & 0.29 & 0.59 \\
\hline Between Spray & $:$ & 0.51 & 1.03 \\
\hline Treatments x Spray & $:$ & 0.72 & 1.46 \\
\hline
\end{tabular}


Table.5 Effect of flubendiamide $20 \mathrm{WG}$ and LAB on Tetrastichus schoenobii in rice in season - 1

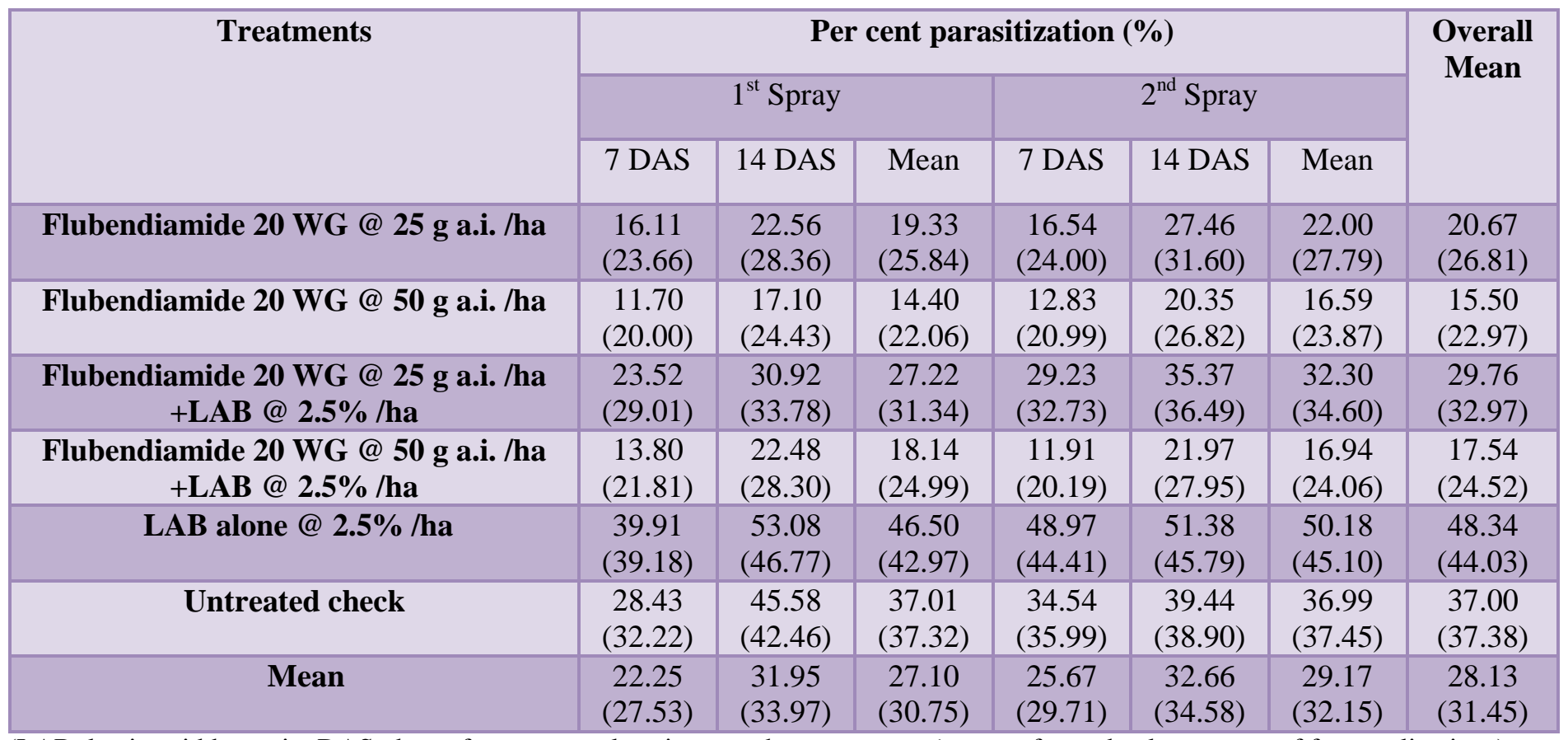

(LAB, lactic acid bacteria; DAS, days after spray; values in parentheses are arc sine transformed values; mean of four replications)

\begin{tabular}{|c|c|c|c|c|c|c|c|}
\hline & & SE.d & $\begin{array}{c}\text { CD } \\
(P=0.05)\end{array}$ & & & SE.d & $\begin{array}{c}\text { CD } \\
(\mathbf{P}=\mathbf{0 . 0 5})\end{array}$ \\
\hline Between Treatments & : & 0.83 & 1.65 & Treatments x DAS & : & 1.16 & 2.33 \\
\hline Between DAS & : & 0.47 & 0.95 & Treatments x Spray & : & 1.17 & 2.33 \\
\hline Between Spray & : & 0.22 & 0.44 & Treatments x DAS x Spray & : & 1.65 & 3.30 \\
\hline DAS x Spray & : & 0.67 & 1.65 & & & & \\
\hline
\end{tabular}


Table.6 Effect of flubendiamide $20 \mathrm{WG}$ and LAB on T. schoenobii in rice in season -2

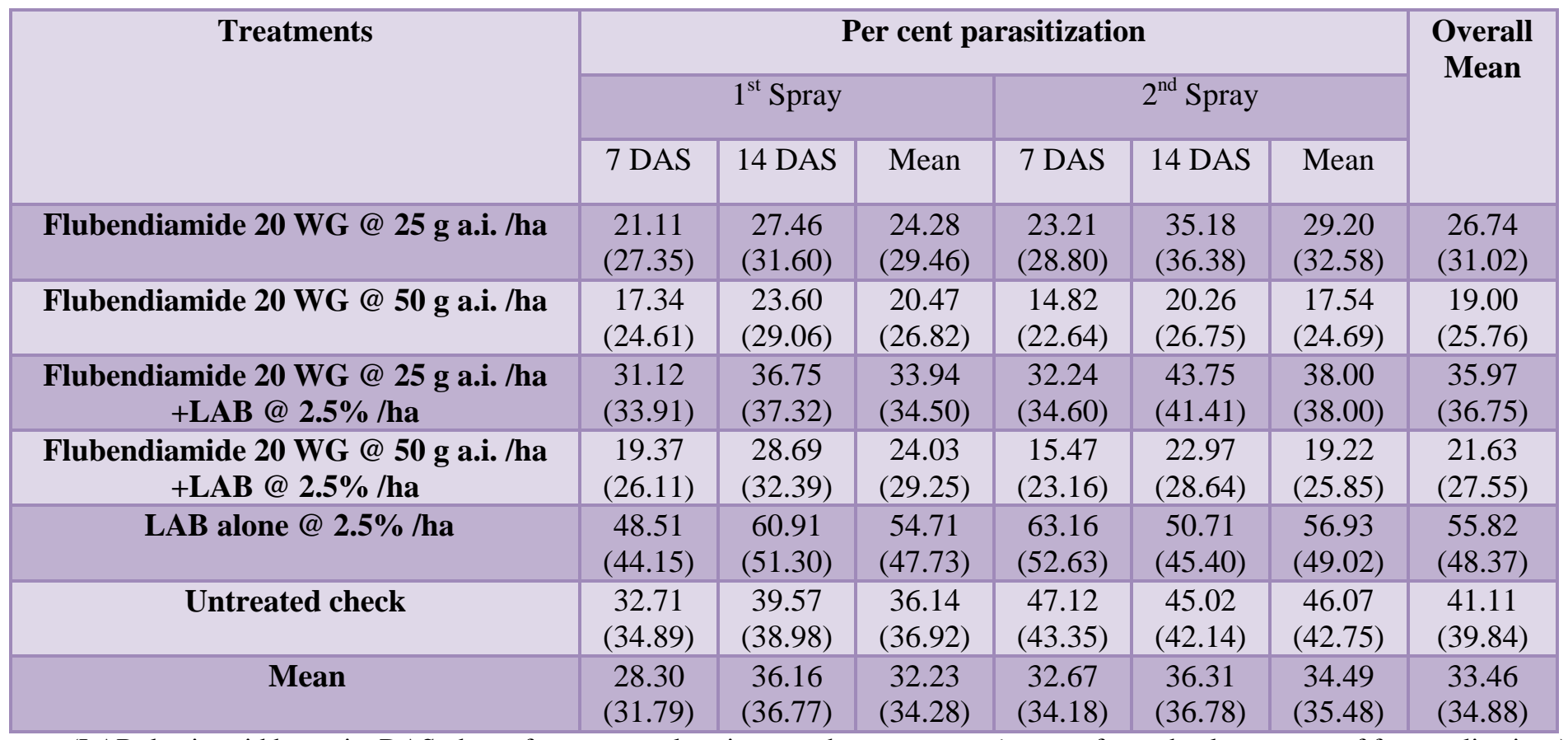

(LAB, lactic acid bacteria; DAS, days after spray; values in parentheses are arc sine transformed values; mean of four replications)

\begin{tabular}{|c|c|c|c|c|c|c|c|}
\hline & & SE.d & $\begin{array}{c}\text { CD } \\
(P=0.05)\end{array}$ & & & SE.d & $\begin{array}{c}\text { CD } \\
(\mathbf{P}=\mathbf{0 . 0 5})\end{array}$ \\
\hline Between Treatments & : & 0.49 & 0.98 & Treatments x DAS & : & 0.69 & 1.39 \\
\hline Between DAS & : & 0.28 & 0.57 & Treatments x Spray & : & 0.69 & 1.39 \\
\hline Between Spray & : & 0.28 & 0.57 & Treatments x DAS x Spray & : & 0.98 & 1.96 \\
\hline DAS x Spray & : & 0.40 & 0.80 & & & & \\
\hline
\end{tabular}


Table.7 Effect of flubendiamide $20 \mathrm{WG}$ and LAB on T. schoenobii in rice in season $-1 \& 2$ (pooled)

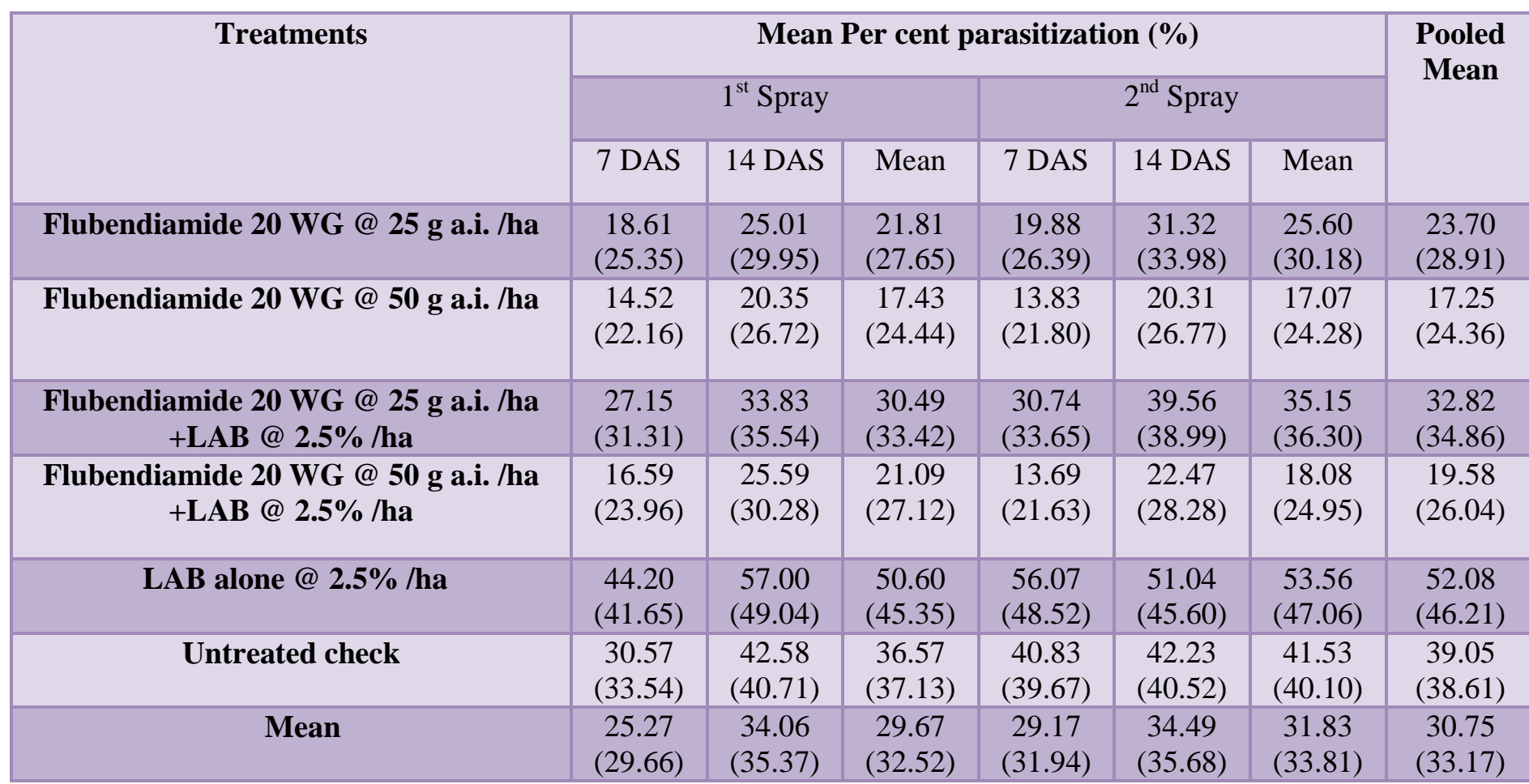

(LAB, lactic acid bacteria; DAS, days after spray; values in parentheses are arc sine transformed values; mean of four replications)

\begin{tabular}{|c|c|c|c|c|c|c|c|}
\hline & & SE.d & $\begin{array}{c}\text { CD } \\
(P=0.05)\end{array}$ & & & SE.d & $\begin{array}{c}\text { CD } \\
(P=0.05)\end{array}$ \\
\hline Between Treatments & : & 0.48 & 0.95 & Treatments x DAS & : & 0.68 & 1.34 \\
\hline Between DAS & : & 0.28 & 0.55 & Treatments x Spray & : & 0.68 & 1.34 \\
\hline Between Spray & : & 0.28 & 0.55 & Treatments x DAS x Spray & : & 0.96 & 1.89 \\
\hline DAS x Spray & : & 0.39 & 0.77 & & & & \\
\hline
\end{tabular}


Table.8 Effect of flubendiamide $20 \mathrm{WG}$ and LAB on Telenomus sp in rice in season -1

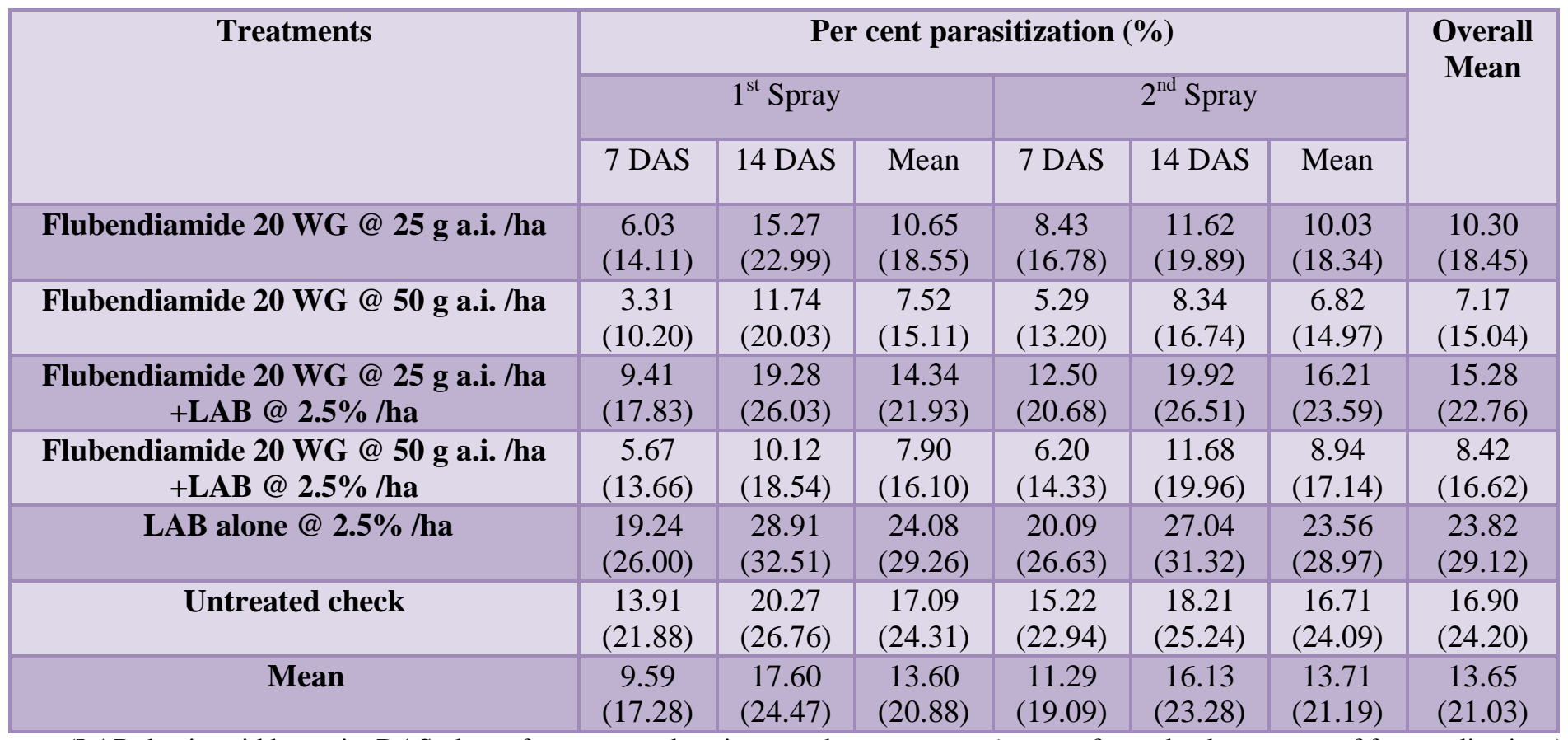

(LAB, lactic acid bacteria; DAS, days after spray; values in parentheses are arc sine transformed values; mean of four replications)

\begin{tabular}{|c|c|c|c|c|c|c|c|}
\hline & & SE.d & $\begin{array}{c}\text { CD } \\
(P=0.05)\end{array}$ & & & SE.d & $\begin{array}{c}\text { CD } \\
(\mathbf{P}=\mathbf{0 . 0 5})\end{array}$ \\
\hline Between Treatments & : & 0.50 & 1.00 & Treatments x DAS & : & 0.71 & 1.42 \\
\hline Between DAS & : & 0.29 & 0.58 & Treatments x Spray & : & 0.71 & 1.41 \\
\hline Between Spray & : & 0.29 & 0.58 & Treatments x DAS x Spray & : & 1.00 & 2.00 \\
\hline DAS x Spray & : & 0.41 & 0.82 & & & & \\
\hline
\end{tabular}


Table.9 Effect of flubendiamide $20 \mathrm{WG}$ and LAB on Telenomus sp in rice season -2

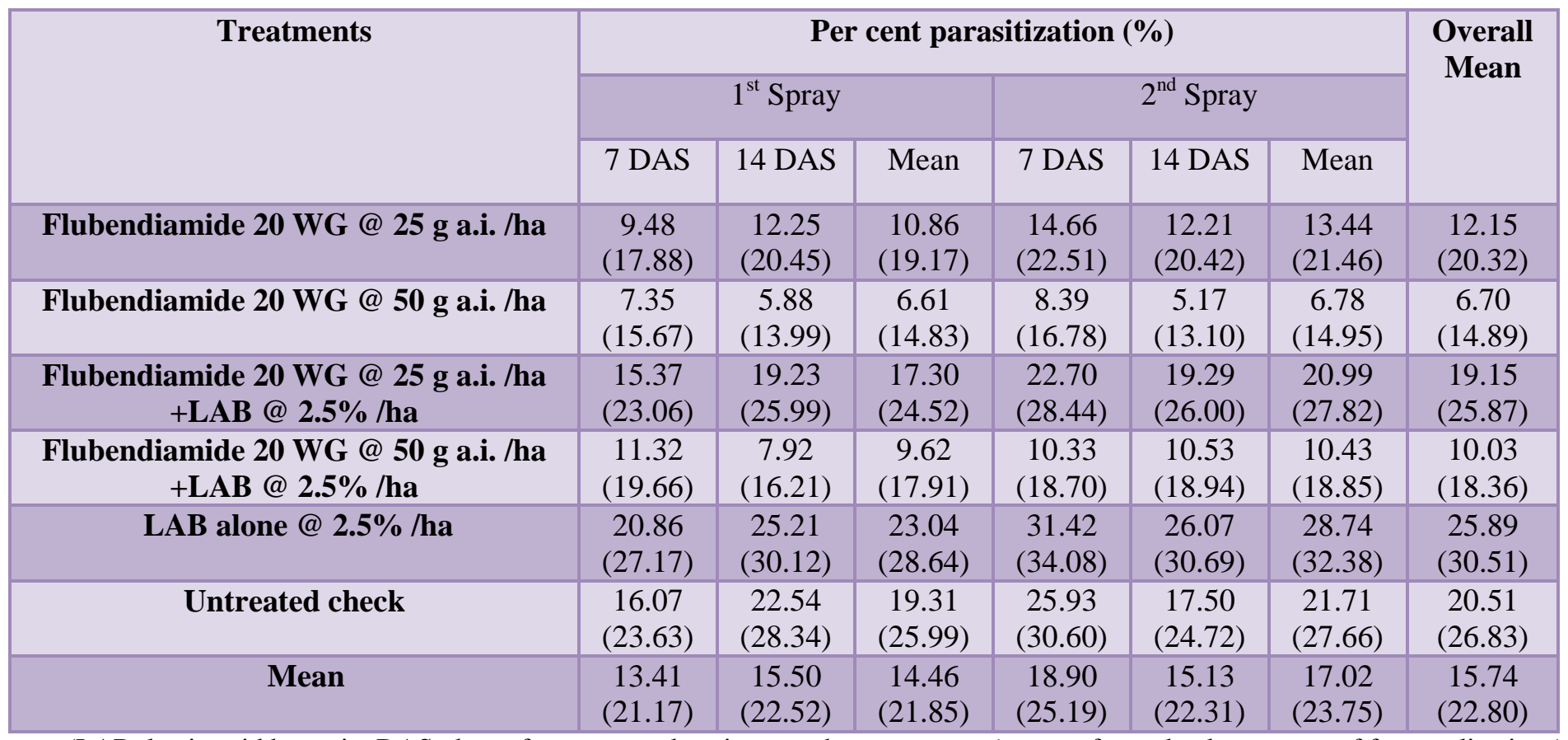

(LAB, lactic acid bacteria; DAS, days after spray; values in parentheses are arc sine transformed values; mean of four replications)

\begin{tabular}{|c|c|c|c|c|c|c|c|}
\hline & & SE.d & $\begin{array}{c}\text { CD } \\
(P=0.05)\end{array}$ & & & SE.d & $\begin{array}{c}\text { CD } \\
(\mathbf{P}=\mathbf{0 . 0 5})\end{array}$ \\
\hline Between Treatments & : & 0.49 & 0.97 & Treatments x DAS & : & 0.69 & 1.37 \\
\hline Between DAS & : & 0.28 & 0.56 & Treatments x Spray & : & 0.69 & 1.37 \\
\hline Between Spray & : & 0.28 & 0.56 & Treatments x DAS x Spray & : & 0.97 & 1.94 \\
\hline DAS x Spray & : & 0.40 & 0.79 & & & & \\
\hline
\end{tabular}


Table.10 Effect of flubendiamide $20 \mathrm{WG}$ and LAB on Telenomus sp in rice season $-1 \& 2$ (pooled)

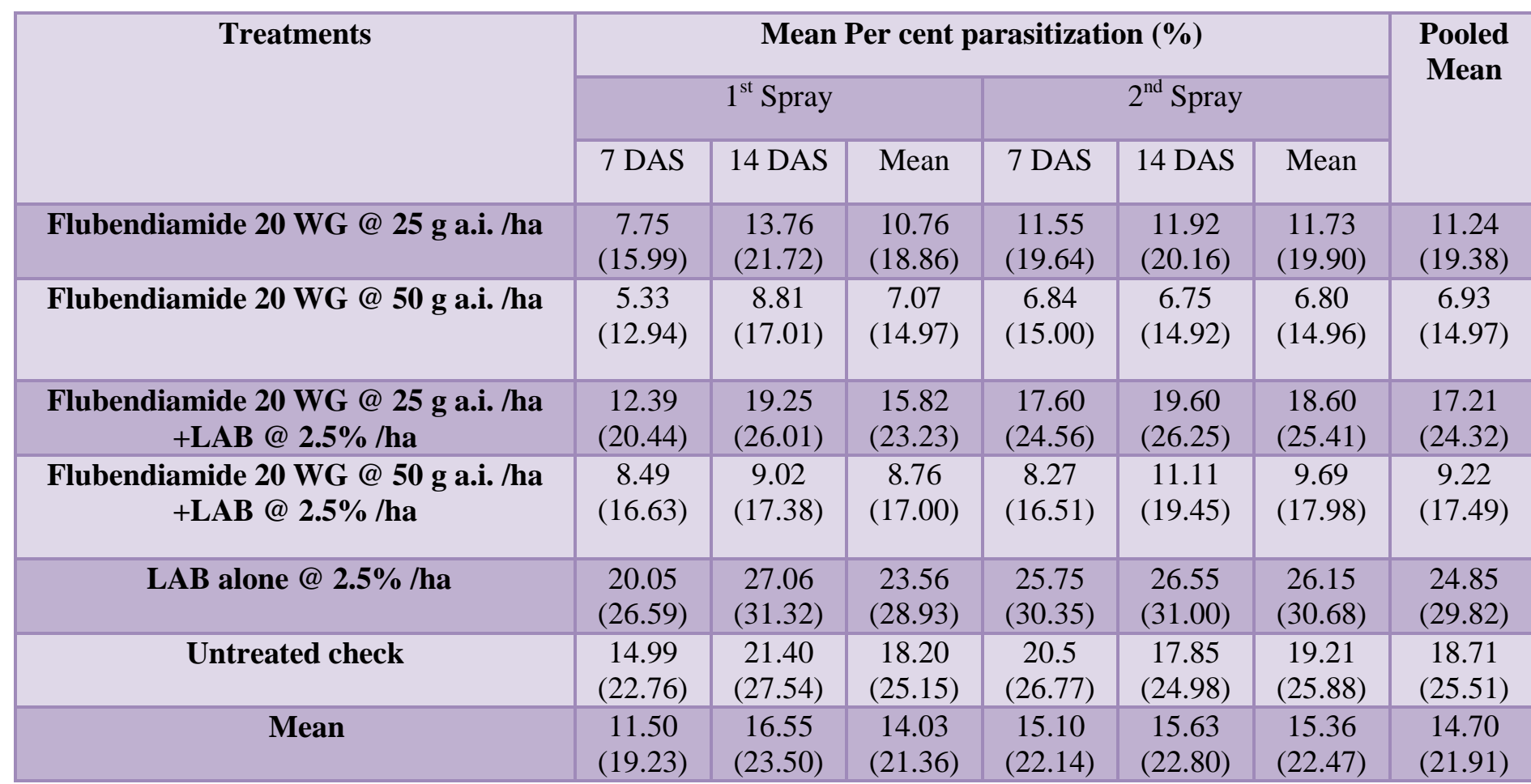

(LAB, lactic acid bacteria; DAS, days after spray; values in parentheses are arc sine transformed values; mean of four replications)

\begin{tabular}{|c|c|c|c|c|c|c|c|}
\hline & & SE.d & $\begin{array}{c}\text { CD } \\
(P=0.05)\end{array}$ & & & SE.d & $\begin{array}{c}\text { CD } \\
(\mathbf{P}=\mathbf{0 . 0 5})\end{array}$ \\
\hline Between Treatments & : & 0.35 & 0.70 & Treatments x DAS & : & 0.50 & 0.99 \\
\hline Between DAS & : & 0.20 & 0.40 & Treatments x Spray & : & 0.50 & 0.99 \\
\hline Between Spray & : & 0.20 & 0.40 & Treatments x DAS x Spray & : & 0.71 & 1.40 \\
\hline DAS x Spray & : & 0.29 & 0.57 & & & & \\
\hline
\end{tabular}


Fig.1 Per cent reduction over control of $S$. incertulas caused dead heart damage. Mean of two season data. $\mathrm{T}_{1}$, Flubendiamide $20 \mathrm{WG}$ @ $25 \mathrm{~g}$ a.i. /ha; $\mathrm{T}_{2}$, Flubendiamide $20 \mathrm{WG} @ 50 \mathrm{~g}$ a.i. /ha; $\mathrm{T}_{3}$, Flubendiamide $20 \mathrm{WG} @ 25 \mathrm{~g}$ a.i. /ha + LAB @ 2.5\%/ha; T,

Flubendiamide $20 \mathrm{WG} @ 50 \mathrm{~g}$ a.i. /ha +LAB @ 2.5\% /ha; $\mathrm{T}_{5}$, LAB alone @ 2.5\%/ha. Vertical bars indicate the SE

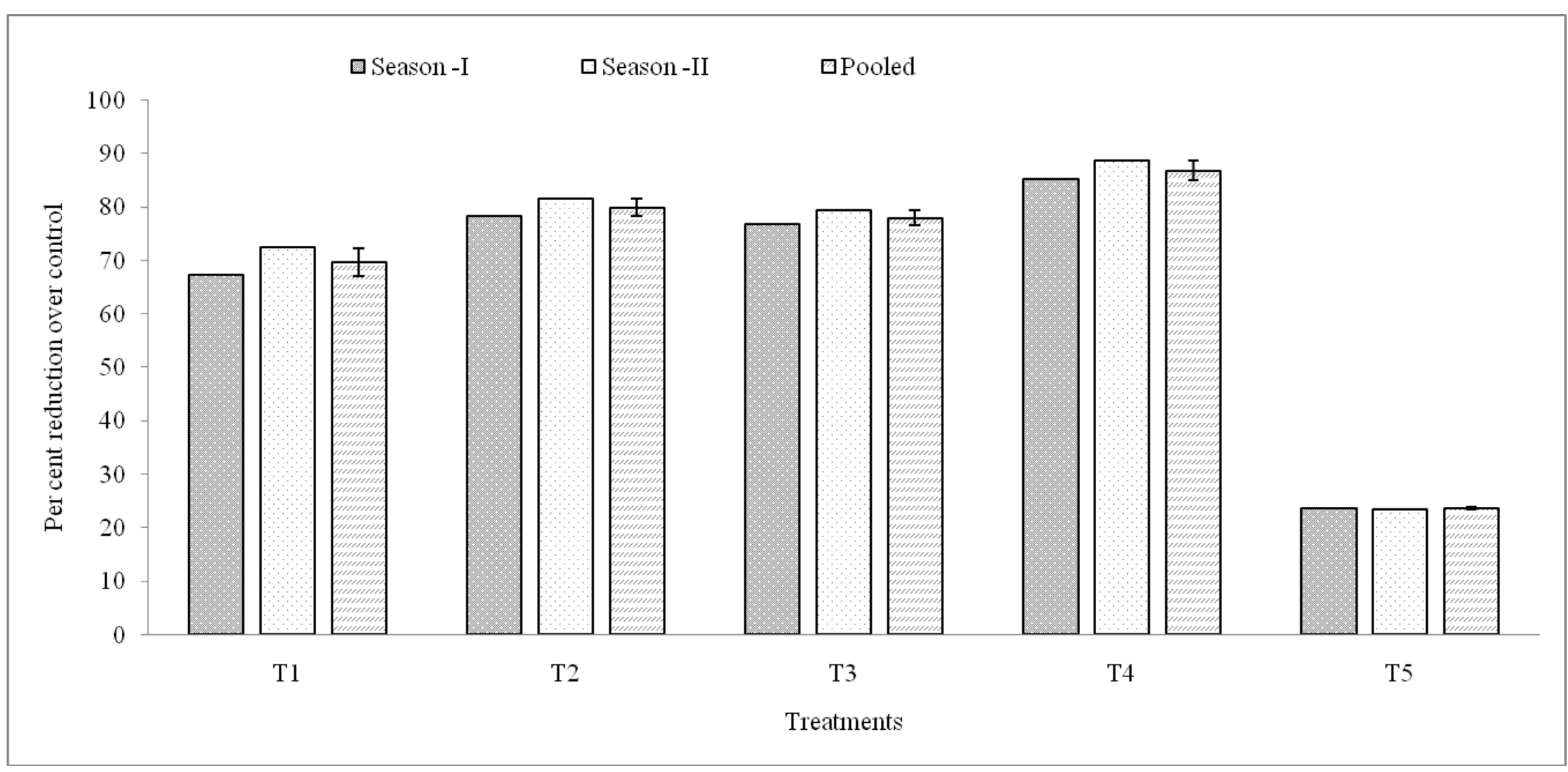




\section{Int.J.Curr.Microbiol.App.Sci (2019) 8(11): 613-633}

Fig.2 The per cent parasitization of egg parasitoids on $S$. incertulas egg mass. Mean of two season data. $\mathrm{T}_{1}$, Flubendiamide $20 \mathrm{WG} @$ $25 \mathrm{~g}$ a.i. /ha; $\mathrm{T}_{2}$, Flubendiamide $20 \mathrm{WG} @ 50 \mathrm{~g}$ a.i. /ha; $\mathrm{T}_{3}$, Flubendiamide $20 \mathrm{WG} @ 25 \mathrm{~g}$ a.i. /ha +LAB @ 2.5\% /ha; T4,

Flubendiamide 20 WG @ 50 g a.i./ha +LAB @ 2.5\%/ha; T5, LAB alone @ 2.5\%/ha; T6, Untreated control. Vertical bars indicate the SE.

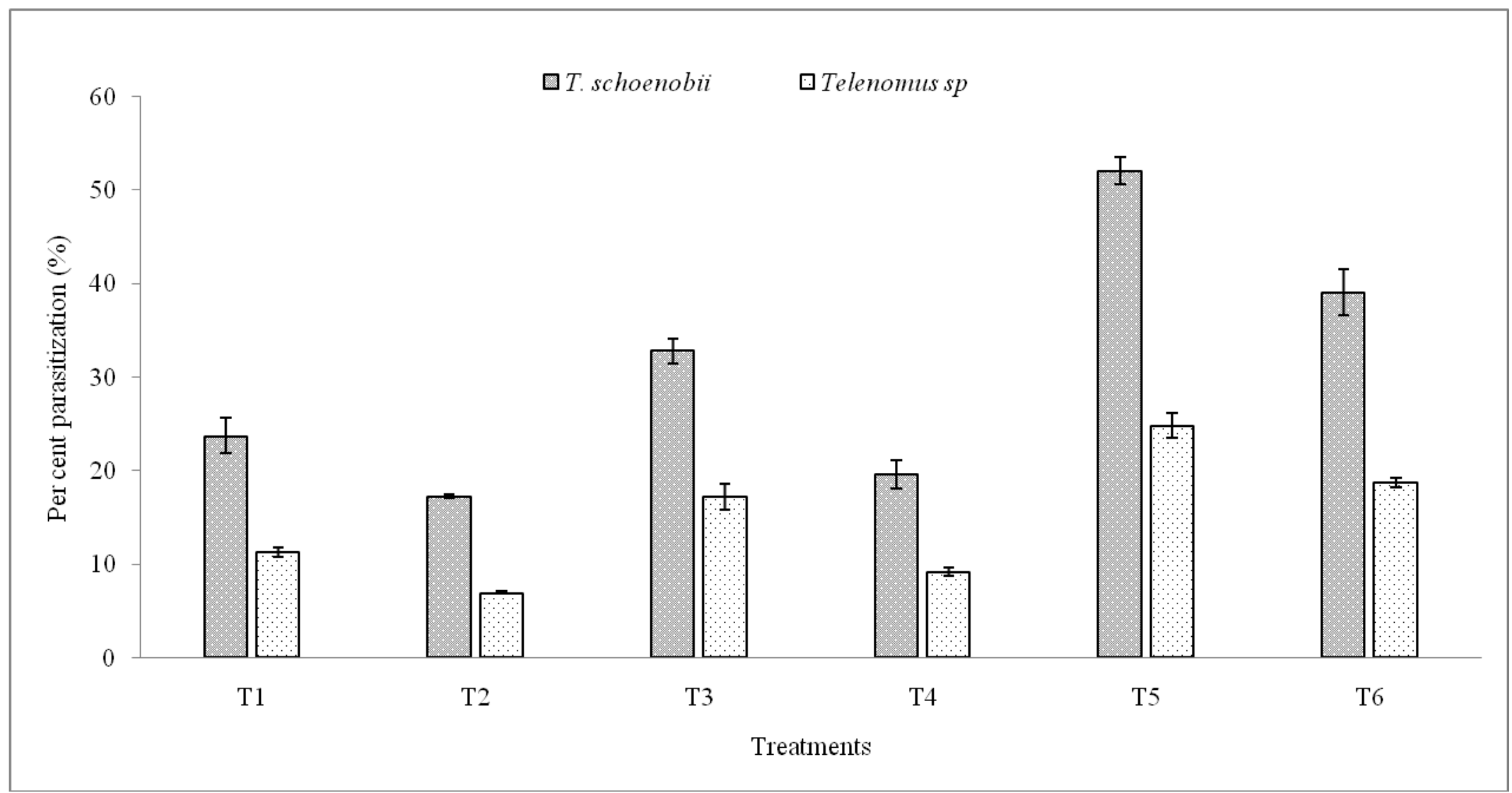


Int.J.Curr.Microbiol.App.Sci (2019) 8(11): 613-633

Plate.1 The egg parasitoids of S. incertulas.

A. Tetrastichus schoenobii

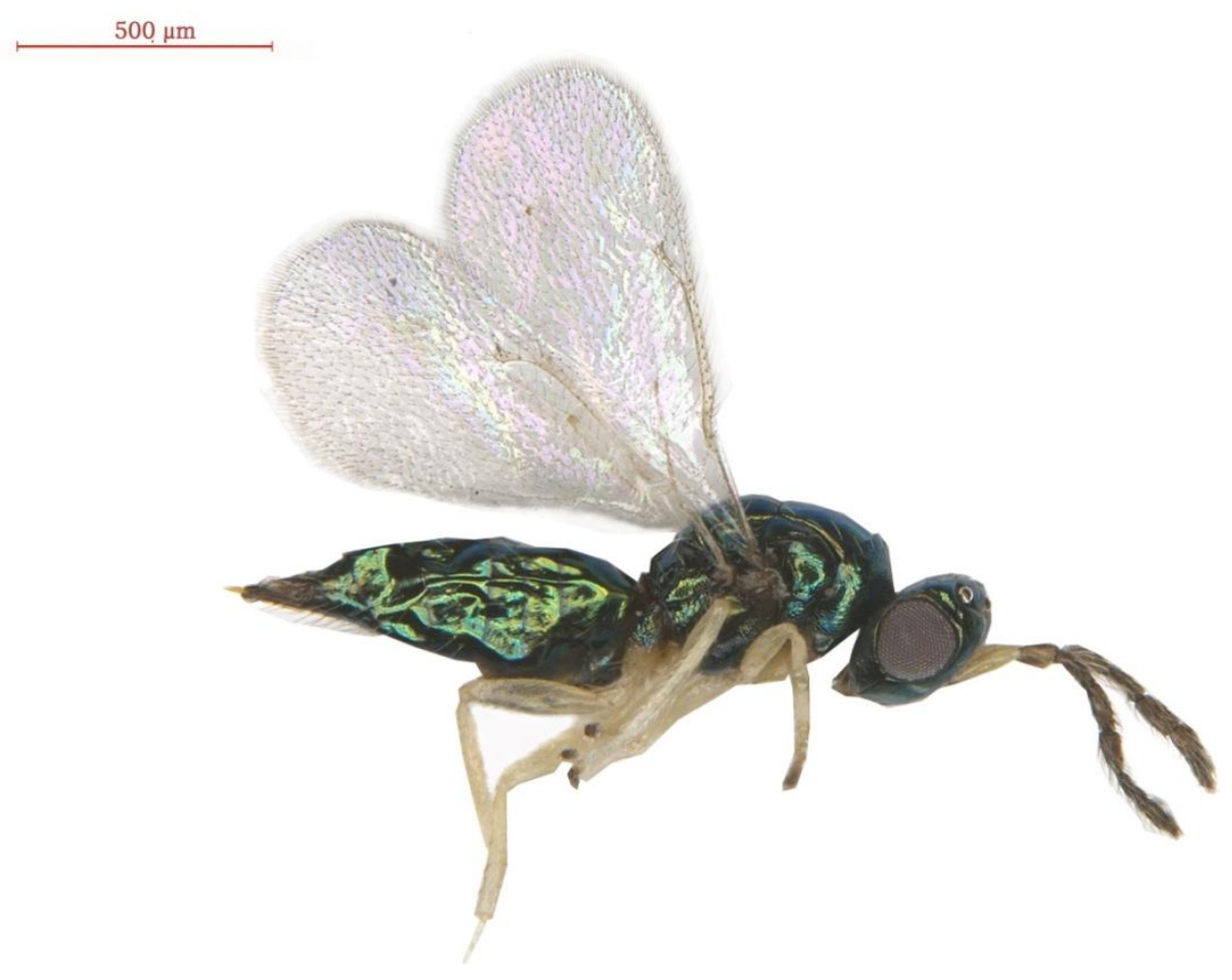

B. Telenomus $\mathrm{sp}$

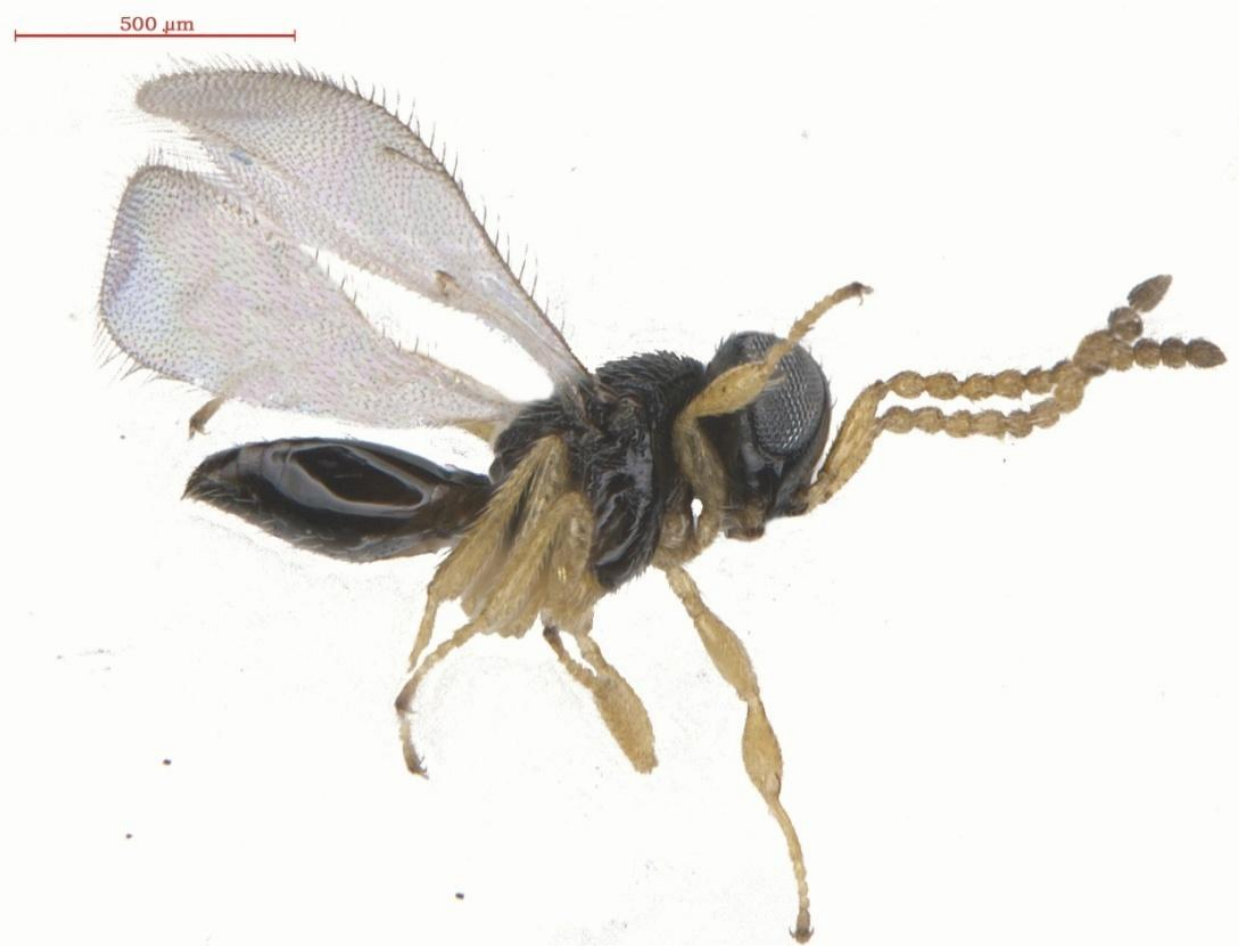


Earlier reports also suggest that flubendiamide was less toxic to beneficial arthropods in rice ecosystem (Tohnishi et al., 2005; Kubendran et al., 2006 and Thilagam et al., 2006). Now it is realized that LAB, especially Lactobacillus, are an indispensable component of sustainable agriculture production, controlling pests, attracting the natural enemies, stimulate plant growth and conditioning soils (Paulsen et al., 2009). It may be concluded that $S$. incertulas can be managed more effectively by spraying flubendiamide $20 \mathrm{WG}$ @ 25 or $50 \mathrm{~g}$ a.i. ha ${ }^{-1}$ in combination with formulated LAB ferments at $2.5 \%$ which is comparatively safer to egg parasitoids, T. schoenobii and Telenomus.

\section{References}

Asghar, M., A. Suhail, M. Afzal, and Khan, M. A. 2009. Determination of economic threshold levels for the stem borers (Scirpophaga sp.) and leaf folder (Cnaphalocrocis medinalis) of rice (Oryza sativa) in the kallar tract of Punjab, Pakistan. Int. J. Agric. Biol., 11: 717-20.

Beasley, S. 2004. Isolation, Identification and Exploitation of Lactic acid Bacteria from Human and Animal Micro biota, Ph.D. Thesis in Microbiology, University of Helsinki, Finland. 57 pp.

Chakraborty, K. 2012. Relative composition of egg parasitoid species of yellow stem borer, Scirpophaga incertulas Wlk. in paddy field at Uttar Dinajpur, West Bengal, India. Current Biotica. 6(1): 4252.

Chatterjee, S., and Mondal, P. 2014. Management of rice yellow stem borer, Scirpophaga incertulas (Walker) using some biorational insecticides. $J$. Biopest., 7:143-147.

David, P.M.M., M. Mathialagan, J. Jeberlin Prabina, K.G. Sabarinathan, K. A. Pushpam, K. Elanchezhyan et al., Government of India Patent Application No. 201841016405 dated 1.5.2018 entitled 'Honey-simulated discriminate fermentation process for preserving perishable juices as probiotics without chemical preservatives'. Patent application filed by Tamil Nadu Agricultural University (TNAU), Coimbatore - 641 003, Tamil Nadu, India. Form 2 Complete Specification, 2018, 12.

Davis, T. S., L. Tawni, R. W. Hofstetter, and Tomberlin, J. K. 2013. Microbial volatile emissions as insect semiochemicals. Journal of Chemical Ecology. 39(7): 840-859.

Devi, P. R., and Singh, K. I. 2016. Efficacy of new molecules against yellow stem borer $S$. incertulas under rice crop ecosystem of Manipur Vally. International Journal of Science, Environment and Technology. 5(2): 5025-532.

FAO/WHO. 2001. Health and nutritional properties of probiotics in food including powder milk with lactic acid bacteria. A joint FAO/WHO expert consultation Cordoba, Argentina. $56 \mathrm{pp}$.

FAO, WFP and IFAD, 2012. The state of food insecurity in the world: Economic growth is necessary but not sufficient to accelerate reduction of hunger and malnutrition. Food and Agriculture Organization, Rome. http://www.fao.org/docrep/016/i3027e /i3027e.pdf.

Food and Agriculture Organization. 2004. Rice is Life. Rome: FAO: Food and Agriculture Organization. June 29, 2013. http://www.fao.org/newsroom/ en/focus/200436887/index. html.

Filya, I., G. Ashbell, Y. Hen, and Weinberg, Z. G. 2000. The effect of bacterial inoculants on the fermentation and aerobic stability of whole crop wheat silage. Anim. Feed Sci. Technol., 88:3946.

Heinrichs, E. A., F. G. Medrano, and Rapusas, H. 1985. Genetic evaluation for insect resistance in Rice. IRRI, Los Banos, Philippines.

Huesing, J., and English, L. 2004. The impact of 
Bt. Crops on the developing world. Ag. Bio. Forum., 7 (1-2): 84-95.

Jadhao, M. F., and Khurad, A. M. 2012. Biology of Scirpophaga incertulus (W.) A Major Pest of Rice in Eastern Vidarbha, Maharashtra. International Indexed \& Refferred Research Journal. 1(1):14-16.

Jiries, A. G., F. M. Al Nasir, and Beese, F. 2002. Pesticide and heavy metals residue in wastewater, soil and plants in wastewater disposal site near Al-Lajoun Valley, Karak/Jordan. Water Air Soil Pollut., 133:97-107.

Kubendran, D., S. Chandrasekaran, B. V. Kumar, and Kuttalam, S. 2006. Assessment of safety of flubendimide $480 \mathrm{SC}$ to naturalenemies. Pestology. 32(12): 19-22.

Kuikui, N., Y. Wang, Y. Cai, and Pang, H. 2015. Natural Lactic Acid Bacteria Population and Silage Fermentation of Whole-crop Wheat. AsianAustralas. J. Anim. Sci., 28(8): 1123-1132.

Lakshmi, V. J., K. Surekha, and Pasalu, I. C. 2010. Parasitization of rice yellow stem borer, Scirpophaga incertulas (Walker) egg masses. Annals of Plant Protection Sciences, 18(2): 366- 369.

Lamont, J. R., O. Wilkins, M. Bywater-Ekegard, and Smith, D. L. 2017. From yogurt to yield: Potential applications of lactic acidbacteria in plant production. Soil Biology \&Biochemistry. 111:1-9.

Madhu Sudhanan, E., S. V. Krishnamoorthy and Kuttalam, S. 2017. Bioefficacy, phytotoxicity, safety to natural enemies and residues of flubendiamide in sugarcane (Saccharum spp. L.) under field conditions. Crop Protection.100: 21-28.

Manju, S. D., Thangaraju and David, P. M. M. 2002. Relationship among abundance of yellow stem borer moths, egg population, and egg parasitism in rice. IRRN, 27: 41.

Maxime, M., N. J. Bostanian, H. M. A. Thistlewood, Y. Mauffette, and Racette, G. 2011. A laboratory assessment of the toxic attributes of six "reduced risk insecticides" on Galendromus occidentalis (Acari Phytoseiidae). Chemosphere. 84(1): 25-30.

Munees, A., and Kibret, M. 2014. Mechanisms and applications of plant growth promoting rhizobacteria: Current perspective. J. King Saud Univ. Sci., 26: $1-20$.

Noumavo, P., E. Kochoni, Y. Didagbé, A. Adjanohoun, M. Allagbé, R. Sikirou, W. Emma, O. Simeon, and Lamine, B. 2013. Effect of Different Plant Growth Promoting Rhizobacteria on Maize Seed Germination and Seedling Development. Amr. J. Plant Sci., 4: 1013-1021.

Ouwehand, A. C., S. Salminen, and Isolauri, E. 2002. Probiotics: an overview of beneficial effects. Antonie Van Leeuwenhoek. 82: 103-279

Prasad, S.S., P. K. Gupta, and Mishra, J. P. 2014. Evaluation of certain new insecticides against yellow stem borer, Scirpophaga incertulas on semi deep water rice, Int. J. Curr. Microbiol. App. Sci., 3(9) :736-740.

Rama Gopala Varma. N., R. Jagadeeshwar and Chitra Shanker. 2013. Relative Composition of Egg Parasitoids of Rice Yellow Stem Borer, Scirpophaga incertulas (Walker) Journal of Rice Research. 6(2):53-58.

Reuolin, S. J., and Soundararajan, R. P. 2017. Egg parasitisation of yellow stem borer, Scirpophaga incertulas (Walker) in rice. Fifth National Conference on Biological Control: Integrating Recent Advances in Pest and Disease Management, National Bureau of Agricultural Insect Resources, Bengaluru., 133p.

Sandhu, G. S., and Dhaliwal, N. S. 2016. Evaluation of different insecticides against major insect pests of rice in Panjab. Int. J. Pl. Prot., 9(1):187-192.

Sekh, K., N. Nair, S. K. Gosh, and Somchoudhary, A. K. 2007. Evaluation of flubendiamide 480 SC against stem borer and leaf folder of rice and effect on their natural enemies. Pestology. 
31(1): 32-34.

Senapati, B., and Panda, S.K. 1999. Rice stem borers. In: Insects of cereals and their management. Applied Zoologist Research Association, Cuttack. pp169.

Shyamrao, I. D., and Raghuraman, M. 2019. Bio-efficacy of insecticides against yellow stem borer (Scirpophaga incertulas Walker) in rice (O. sativa L.) ecosystem of Varanasi region. Journal of Pharmacognosy and Phytochemistry. 8(2): 301-304.

Silva, D. R., E. Ferreira and Vieria, N. R. A. 2002. Evalution of upland rice losses caused by Oebalus spp. (hemíptera: pentatomidade). Pesqui Agropecu Trop., 32 (1): 39-45.

Stiles, M. E., and Holzapfel, W. H. 1997. Lactic acid bacteria of foods and their current taxonomy. Int. J. Food Microbiol., 36 (1): 1-29.

Stiles, M.E. 1996. Biopreservation by lactic acid bacteria. Antonie van Leeuwenhoek, 70: 333-345.

Thilagam, P. 2006. Evaluation of flubendiamide 480 SC against bollworm complex in cotton and leaf folder and stem borer in rice. $\mathrm{Ph}$. $\mathrm{D}$. thesis submitted to TNAU, India. p. 232.

Tindall, K.V., B.J. Williams, M. J. Stout, J. P Geaghan, B. R. Leonard and Webster, E. P. 2005.Yield components and quality of rice in response to graminaceous weed density and rice stink bug populations.
Crop Prot., 24 (11):991-998.

Tohnishi, M., Nakao, H., Furuya, T. Kodama, A. and Nishimatsu, T. 2005. Flubendiamide, a novel insecticide highly active against lepidopterous insect pests. J. Pestic. Sci. 30(4): 354360.

Venu, I., Z. Durisko, J. Xu, Dukas. R 2014. Social attraction mediated by fruit flies microbiome. Journal of Experimental Biology.217(8):13461352.

Wanumen, A. C., G. A Carvalho, P. Medina, E.Viñuela and Adán, A. 2016. Residual acute toxicity of some modern insecticides toward two mirid predators of tomato pests. Journal of Economic Entomology, 109(3), 1079-1085.

Yunus, M., N. Ohba, M. Shimojo, M. Furuse and Masuda, Y. 2000. Effects of adding urea and molasses on napiergrass silage quality. Asian-Australas J. Anim Sci. 13:1542-1547.

Yu, Y., and Zhou, Q. X. 2005. Adsorption characteristics of pesticides methamidophos and glyphosate by two soils. Chemosphere, 58: 811-816.

Zhang, Y. H, D. Xu, J. Q. Liu, and Zhao, X. H. 2014. Enhanced degradation of five organophosphorus pesticides in skimmed milk by lactic acid bacteria and its potential relationship with phosphatase production. Food Chemistry. 2014; 164:173-178

\section{How to cite this article:}

Arulkumar, G., Y.S. Johnson Thangaraj Edward, K. Bhuvaneswari, P. Jeyaprakash, N. Chandra Sekaran and Senthilkumar, M. 2019. Effects of Flubendiamide and A Lactic Acid Bacterial Formulation on Stem Borer Scirpophaga incertulas Walker and its Parasitoids in Rice. Int.J.Curr.Microbiol.App.Sci. 8(11): 613-633. doi: https://doi.org/10.20546/ijcmas.2019.811.075 